\title{
Building networks among info pros
}
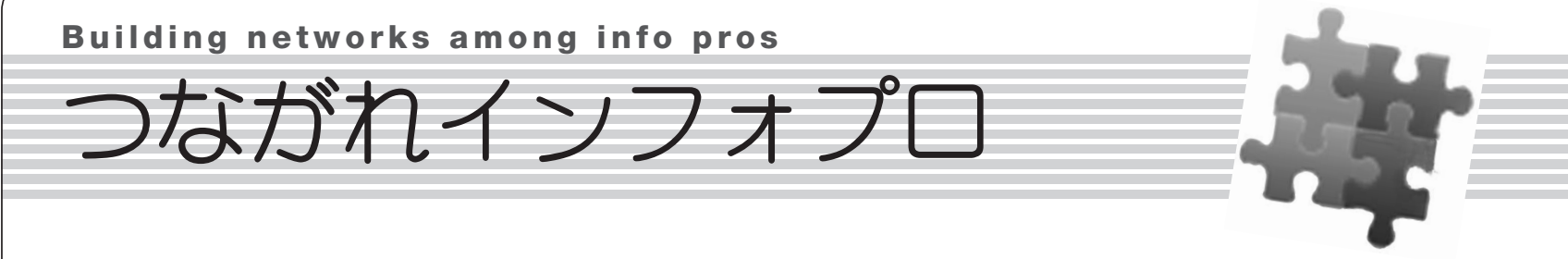

第 12 回

須藤 公夫（大塚製薬株式会社 知的財産部）

情報管理５7(6), 417-419, doi: 10.1241/johokanri.57.417 (http://dx.doi.org/10.1241/johokanri.57.417)

\section{FARMDOC 協議会とは}

日本FARMDOC協議会（以下，JFA）の母体は， 1963年に始まったDerwentの医薬関連特許情報サー ビス「Farmdoc」に採用された各種の索引システム を勉強し，改善を訴えるために集まったユーザー会 「Farmdoc 会員協議会」（初会合は1966年）である。 1968年に会則等を整備し，設立総会を開催し，正式 に設立した。活動の目的は製薬会社(または関連機関) の特許情報を扱う部署のメンバーによる交流とスキ ルアップである。

現在会員会社は23社で，会員には研究会に参加す ることと，順番で運営役員として活動することが義 務づけられている。毎年8月ごろに研究テーマを募り， 各自の参加表明・メンバ一調整を経て，9月ごろ4〜 5グループを確定する。テーマ内容に沿った調査や解 析を月に1回程度の会合でまとめ，5月に一堂に会し てその発表会を行う。総会も併設され，1年の活動報 告，次年度役員の確認を行い，8月のテーマ募集まで に引き継ぎを行う（図1～図3）。

私は1992年ごろから参加しており，最古参の1人で ある(それゆえもはや末席を污す身であるにもかか わらず，代表より執筆依頼の栄誉を得た者である)。

\section{JFA の変遷}

発足の経緯にあるように，もともとはDerwent の「Farmdoc」というコンテンツのユーザー会と して始まっている。「Manual Code」や「Chemical Fragmetation Code」はDerwentのCPI (Central Patents Index) フル会員でなければ利用できない
という制限があったため，JFAでも参加メンバーは Derwent会員であることが条件で，研究会のテーマ もWPI（World Patents Index）に関することを絡める のが通常であった（初期にはChemicalCodeマニュア 儿翻訳という活動もあつた)。

JFAは発足当時から研究会を活動の中心に据えてい

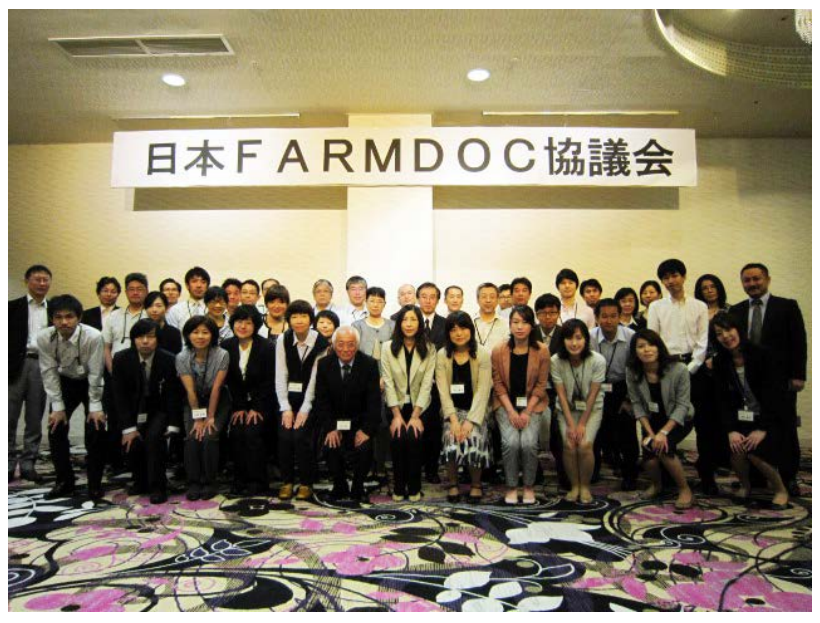

図1２013年度研究発表会集合写真

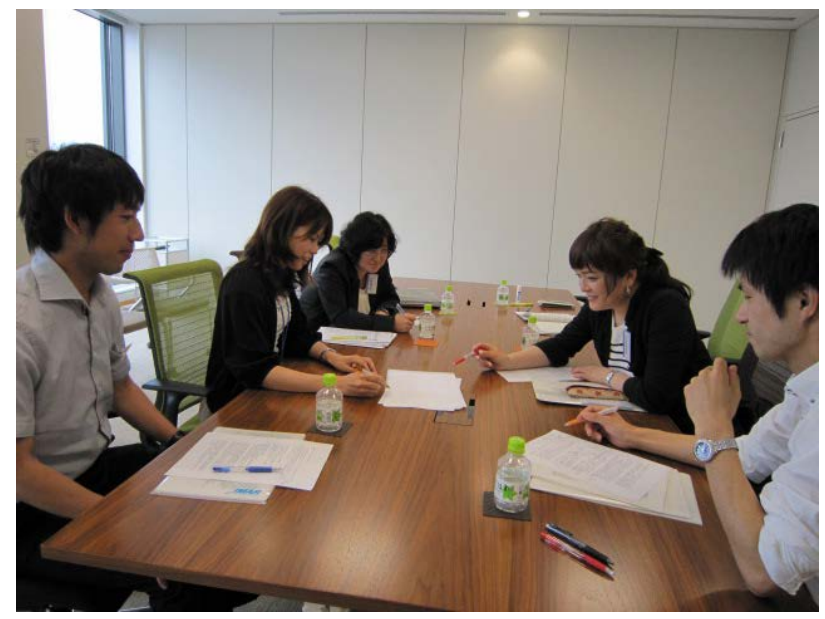

図2２014年役員引き継ぎ風景 


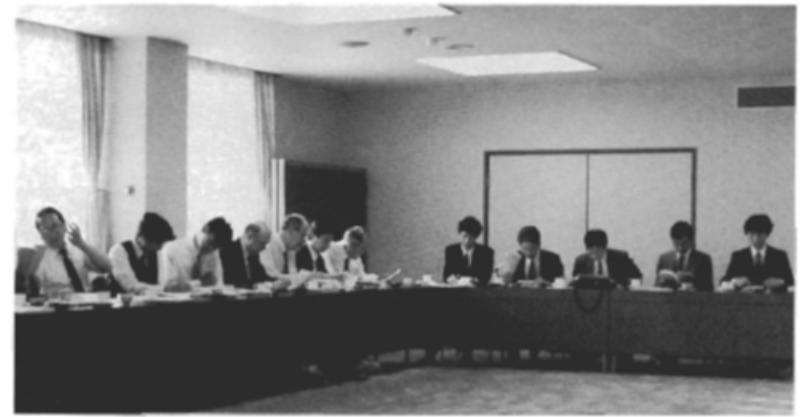

図3 総会風景

て，当初はデータベース（WPI等）の機能や使い勝手， データの正確性，索引の評価など，データベースの 内容そのものを研究の対象とすることが多かった。 また，1社ではなかなかできない規模の大きな検証作 業をすることでデータベース作成側に根拠のある改 善要望をつきつけるなど，データベースが限られて いたがゆえの圧力団体的な性格（いい意味でのユー ザーとベンダーとの緊張関係）があったと思う。

また，かつてはデータベースを扱うこと（検索作 業そのもの）にスキルが必要で，かつ利用料金が高 価であったため，その技術やノウハウを互いに伝え 合うことも大きな目的の1つであつた（図4，図5）。

時代が移り，「特許は著作権なし，無料公開情報」 という原則にデジタル技術の発展が加わり，各国の 特許庁から1次情報として公開されるようになった （当初こそCD-ROM媒体などでの公開で，その検索閲 覧システムと抱き合わせで高值で販売され，その評 価が研究会テーマになったこともあったが，間もな くWebも充実して媒体販売は廃れた)。

WPIは「索引つきの情報」としての価値を保ち続け ていたものの，「会員制度」で維持するというモデル は成り立ちにくくなり，CPIの「ChemicalCode」以 外の情報は会員資格なしで利用できるようになって いった（その後Derwent自体が買収されてしまった ことは象徵的である)。

前述のように特許情報のWeb公開に伴って各国特 許庁のシステムも充実し，公開データを利用した多 彩な全文検索システムが出現し，またさまざまな統

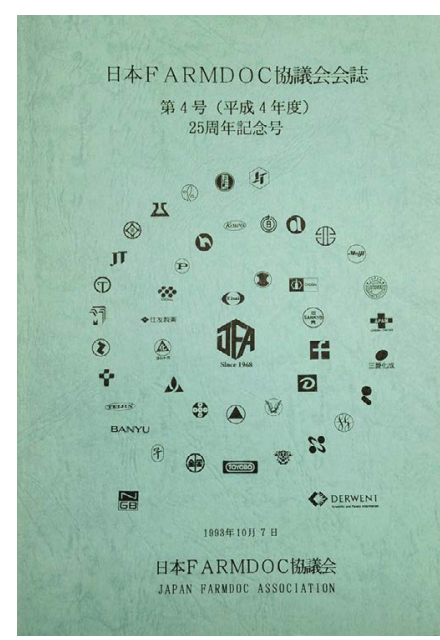

図4JFA会誌（25周年記念号）

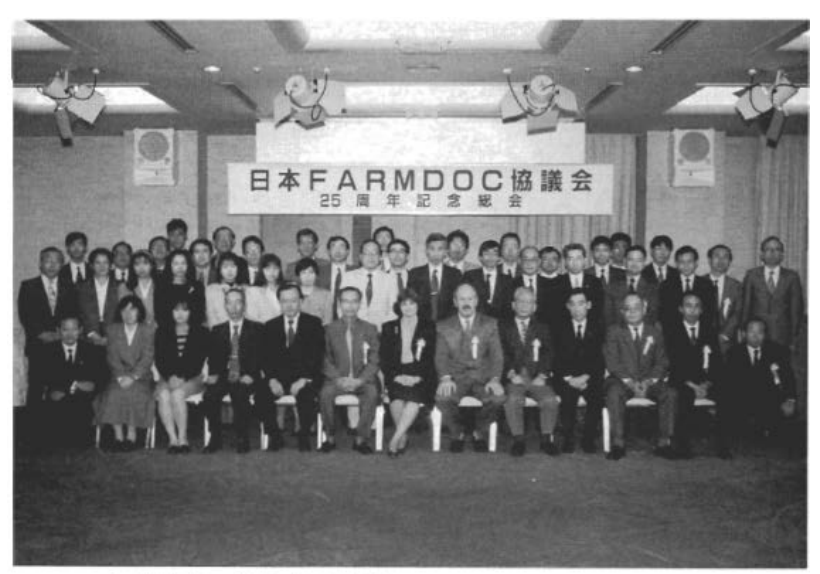

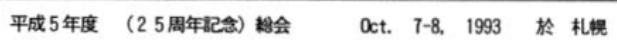

図5２5周年記念総会

合データベースに特許情報が載るなど，JFAで扱う内 容も多岐にわたるようになった。

また，経済情勢もあり，製薬会社でもフル会員を やめるところが多くなったことやそれまでJFAに協力 的であったDerwent自体が事実上「会員サポート」を やめてしまったことで, Derwent会員であることを JFA参加資格とする意味がなくなった。

さらにこのころ製薬各社で間接部門への風当たり が強くなり，「調査」部門の統廃合，分社化等の切り 離し，アウトソーシングなどで，JFAに参加する人員 確保が難しい等の理由による脱退や，会員会社の合 併による会員数減少があり，会の運営上も，「役員に 権限をもたせ，合議（根回し）で役員を選出して複 数年運営にあたらせる」という従来の運営方法では 
役員のなり手を探すことが困難になった。会員の「定 義」としても「製薬会社」に限定することへの疑問 も出てきた。

そこで，2003年度の活動においてワーキンググ ループを作って会則改定を提案し，（1）会員資格変 更（Derwent会員の条件削除，製薬会社とは限定せ ず関連調査を業務とする団体も受け入れる等)，

運営役員の負担軽減と輪番制導入，年会費の廃止（会 費から研究会の運営費を出すという金の流れをやめ， 出納を東西合同発表会・総会の開催のみに限り，会 費のプールを少なくして役員の会計業務負担を減ら す）などの改革を行った。会則自体も，会則（本則） と細則（運営則）に分けて柔軟に運営できるように 変更した。その後の会運営の流れは，上記のように ルーティン化している。細かい会則改定は適宜行わ れている。

現在のJFAは若手の参加も増え，特許情報に限らな いテーマ（動向解析など）の研究や意見交換も活発 で，活気を取り戻しつつある。ただ，参加を広く認 めているとはいえ，基本的に現在の会員の推薦を条 件にしており，研究会活動に有料データベースを用 いたり（その費用は各社負担），研究会の会合の場所 を各社持ち回りで提供したり（東西の支部分けがな くなったため遠距離出張もしばしば必要），輪番で会 運営に携わったりするため，ある程度以上の「企業」 でないと難しいので, 会員数は拡大していない。また， 研究会以外の活動を支援できるような運営体制では ないため，その紹介の場（Webサイトなど）もなく， かなりクローズドな団体である（クローズドならで はのよさもあるが)。ただ発表された成果は各社に持 ち帰り，社内共有することはできる。

\section{製薬特許を扱うインフォプロの立場}

『情報管理』誌の過去の投稿にもあったと思うが， 高速ネット，強力検索エンジン，ビッグデータが当 たり前の世の中となり，調査という業務に対する評
価や組織的な存在感が薄れているのは確かなことで ある。索引に頼らない全文検索やマイニング技術が 注目され，調査そのものは評価されにくい。

資料の面からいえば旧Derwentの資料はその Documentation Abstractに代表される索引者抄録を 特徵とする人間味あふれる資料であったが，出願の 増加に対応できず，その抄録クオリティは下がっ ている。量的なことへの対応ではCAS (Chemical Abstracts Service）など他の索引データベースでも同 じである（トムソン・ロイターやCASという大組織で さえも索引に機械的な処理による部分が多くなって (る)。また，システム自体にもコストダウンの影響 がみられる。にもかかわらず，作成コストの名のも とに年々值上がりしていて，調査コストに跳ね返り， 調査担当者は頭が痛いと感じている向きも多いので はないだろうか。

このような状況の中，製薬関係の資料はその特殊 性・多面性から調査そのものにある程度のスキルを 必要とするうえに，結果に対する評価も重要であり， 単なる「検索屋」にとどまらない「インフォプロ」 としての存在価値は高いと信じている。特許調査に おいても，医薬特許の特殊性，化学構造や配列など へのアプローチのスキルの価値は昔と変わらない。 JFAのような「学びと経験の場」を利用して，いか に効率的かつ網羅的に目的の調査をするか，いかな るデータベースがありどう使うとよいのかという知 識とノウハウを蓄積することは非常に重要な意味を もっていると確信している。

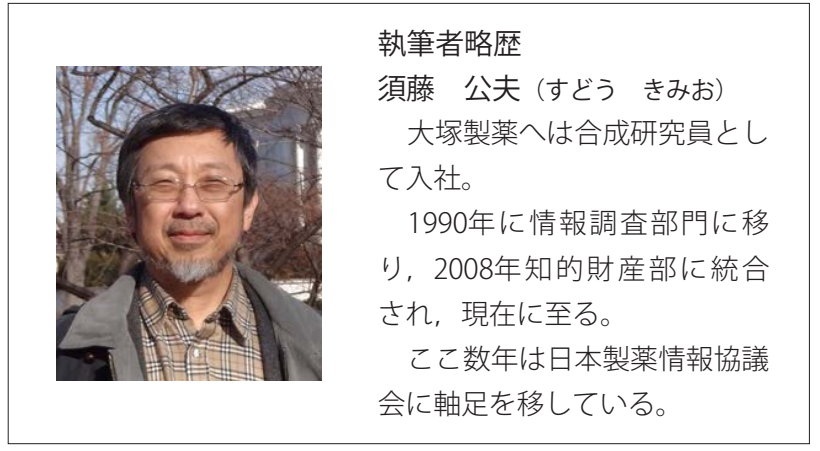

